\title{
Article \\ There Are No Schools in Utopia: John Dewey's Democratic Education
}

\section{Ian T. E. Deweese-Boyd}

A map of the world that does not include Utopia is not worth even glancing at, for it leaves out the one country at which Humanity is always landing. And when Humanity lands there, it looks out, and, seeing a better country, sets sail. Progress is the realization of Utopias.

(Oscar Wilde 2001, 141)

"The most utopian thing in Utopia is that there are no schools," writes John Dewey $(1933 / 1989,136)$. With these words, Dewey opened his talk to kindergarten teachers on April 21, 1933 at Teachers College, Columbia University. Published a couple days later in the New York Times under the title, "Dewey Outlines Utopian Schools," we find Dewey in this little-discussed talk fancifully imagining himself among the Utopians-somehow transported from the economically depressed United States of the 1930s to Utopia, where the economy of acquisition is nothing but a memory. ${ }^{1}$ Finding himself in Utopia, Dewey, of course, asks about the schools, quizzing the Utopians on everything from their pedagogy to their educational goals. What he discovers is a radical critique of education as it was (and still is) often practiced. The emphasis on standards and the competitive and punitive systems of examinations that enforce them appear deeply misguided to the Utopians. They contend that it is our economic system and its emphasis on "personal acquisition and private possession" that has reduced education to the mere acquisition of facts, necessary for the further acquisition of things. According to the Utopians, once their acquisitive economy had passed away, education itself was transformed, liberated in a way that enabled teachers to concentrate their attention on identifying and developing the unique capacities of each student. Instead of a single-minded focus on delivering the facts of the curriculum, the Utopians were able to see the child as the gravitational center of the educational enterprise.

The contemporary conversation about education in America, and in many other western educational contexts, could not be further from this vision. American society is more driven by acquisition than ever, and its children are exposed to an unprecedented onslaught of advertising aimed at training them in the practice of consumption. ${ }^{2}$ In school, the same children are scrutinized by high-stakes, standardized examinations that stand as the goal and measure of learning. Education itself-in 


\section{Ian T. E. Deweese-Boyd}

the context of a consumption-oriented society- becomes a commodity among commodities. This situation, I argue, gives us good reason to consider Dewey's Utopians and his own democratic prescription for educational and societal transformation.

After offering an overview of the Utopian's educational vision, along with their understanding of the obstacles keeping schools from realizing this vision, I will examine the objection that the Utopians (and Dewey) naïvely reject the reality of economic motivation in learning. A consideration of Dewey's own understanding of curriculum, vocation, and democracy-which underwrites the Utopian's vision and critique-shows this objection to be largely misplaced. Far from overlooking the influence that economic motivation plays in education, Dewey sees that this motivation itself can be a threat to the attitudes necessary for truly democratic ways of living.

\section{Dewey's Outline for Utopian Schools: The Vision}

As Dewey's first line suggests, there are no schools of the traditional sort in Utopia. With orchards, gardens, greenhouses, wilderness, workshops, kitchens, and chemistry labs, children are given ample space to encounter the realities of the world and to discover and pursue their particular interests. The classrooms themselves are open, flexible spaces that facilitate face-to-face interaction. Combined with a limit on size-less than two hundred pupils-these schools support the "close, intimate personal acquaintance" necessary for genuine engagement (Dewey 1933/1989, 135). Education itself is a sort of apprenticeship in which children work with adults and older peers, gradually taking on responsibilities commensurate with their developing capacities. Engaged in real occupations, working alongside masters-who "combine special knowledge of the children" with expertise in a certain area (Dewey 1933/1989, 137) - they encounter the content of what we call the curriculum in a context that gives it both meaning and point. ${ }^{3}$

At the center of Dewey's utopian vision, or as he puts it, at the center of the Utopian's vision of education, is the identification and cultivation of each child's unique capacities. When he asks the Utopians about the objectives of their educational activities, he gets blank stares-they don't understand the question; they don't conceive of education as having measurable objectives like the meeting of standards. But, based on his observations, he reckons:

The fundamental purposes were thoroughly ingrained in the working of the activities themselves. In our language, [the objective] might be said to be the discovery of the aptitudes, the tastes, the abilities and the weaknesses of each boy and girl, and then to develop their positive capacities into attitudes and to arrange and reinforce the positive powers so as not to cover up the weak points but to offset them. (Dewey 1933/1989, 138)

Accordingly, Utopian educators seek "to find out what each individual person [has] in him from the beginning, and then devote themselves to finding out the conditions of the environment and the kinds of activities in which the positive capaci- 
ties of each young person could operate most effectually" (139). Given an environment in which to pursue their intrinsic interests and to exercise their growing capacities, Dewey's Utopians argue, the process of learning is itself immediately enjoyable, not something simply to get through for the sake of some future joy. The attitude that sustains such learning is what Dewey calls a "positive sense of power," a kind of confidence and pleasure in the exercise and growth of one's capacities. This attitude, shaped and sustained by the educators and the school alike, involves the "elimination of fear, of embarrassment, of constraint, of self-consciousness; eliminat[ion, in short, of] the conditions which create ... the feeling of failure and incapacity" (140). Equipped with the fortitude this sort of education grants them, these students emerge from their education ready and willing to do work that both matches their capacity and serves society; they will also be eager to discover and solve the problems that inevitably arise along the way. Accordingly, these students will be happy and capable in their work, and though he doesn't mention it explicitly, Dewey implies that they will have developed the ability to identify the social conditions necessary to sustain their good work as well as that of their neighbors.

According to Dewey's Utopians, our schools (for now let's assume a family resemblance) fall short of this ideal, because our acquisitive economic system has so infiltrated our consciousness that we find it difficult to see learning as anything but the acquisition and storing away of facts. The relentless drive to possess or consume extends to education by reducing knowledge to another commodity. Emphasis on getting this commodity, according to the Utopians, has the effect of displacing the work of "creating attitudes by shaping desires and developing needs that are significant in the process of living" - the central task of education in their view $(1933 / 1989,139)$. It isn't simply that the schools don't actively cultivate such attitudes, but that their goals and methods themselves create conditions that may well stifle them. For example, to ensure the acquisition of the standards, schools employ "competitive methods of appeal to rivalry, the use of rewards and punishments, of set examinations and systems of promotion" (139). These competitive methods, the Utopians imply, ensure self-consciousness, fear of failure, and incapacity for many if not most students. Extrinsic rewards and punishments undermine intrinsic motivation, transforming the curriculum into an unpleasant means, valuable only for what it can help one get. "So it was," according to the Utopians, "that we had come to regard all study as simply a method of acquiring something, even if only useless or remote facts, and thought of learning and scholarship as the private possession of the resulting acquisition" (139). Alienated from learning in school, these children will be alienated from work as adults, forever acquiring and yet never gaining the prize. The motto of these schools, according to the Utopians, is that "man never is, but always is to be, blest" (139). This education, conditioned as it is by the acquisitive economic society, serves to perpetuate a society that measures achievement and success in purely economic terms, that inevitably has economic winners and losers, and that forces many to choose economic survival over vocational fulfillment. 


\section{Ian T. E. Deweese-Boyd}

In contrast to the Utopian society, where this economic model has been abolished, those who emerge from this education are not likely to know what their particular capacities are or what they enjoy doing. Instead, insofar as they are interested in their abilities, they value them for the economic benefits they may afford them. In this way, they end up objectifying not only the curriculum, but also their own capacities. Their value, even to themselves, is largely economic in nature.

\section{Utopianism in Education: An Objection to Dewey's Vision}

With the Utopians' vision and critique in view, we can now consider whether this vision is realistic. In his own day, Dewey was accused of being utopian in his views about education and democracy-no doubt that is part of the joke behind his talk-and the Utopians turn out to be advocates of Dewey's philosophy of education. While Dewey's stock has certainly risen since then, skepticism toward his educational vision is still relatively easy to find. For example, Alexander Sidorkin (2009) argues that Dewey's vision is hopelessly utopian, precisely because it systematically ignores the role economic interest must play in motivating learning. ${ }^{4}$ Dewey, in short, is utopian-read naïve-in his belief that learning can and should be motivated primarily by intrinsic interests rather than extrinsic economic ones. ${ }^{5}$ Sidorkin's view that economic interests must be used to motivate learning, since such interests motivate all work, is itself emblematic of the perspective Dewey saw as so corrosive to any education that would lead to social progress and reform. Consequently, examining Sidorkin's objection helps to clarify why Dewey thought the acquisitive economy represented such a danger both to education and to democracy. In particular, it will help us to see how Dewey's understanding of the curriculum and of vocation underwrite his and the Utopians' emphasis on developing intrinsic interests over and above extrinsic economic ones.

Sidorkin (2009) takes the principle attribute of utopias to be that they "ignore people's material interests and the limits inherent in any social institution" (191). He clarifies his notion of educational utopianism further this way: "Children's wishes and interests are important to Dewey, but their economic reasoning is simply invisible to him. Dewey assumes that we can expect children to perform any amount of work in school, if we only select and organize such work properly. This thinking leads to the utopian concept of education that simply does not take into account the limits of what schooling can and cannot deliver, and how much we can ask children to do" (191).

Sidorkin goes on to argue that we should recognize that "the sum total of children's activities, including play and useful occupations, cannot generate the interest sufficient to ensure students' motivation to learn the school curriculum, however it is reformed or redefined" $(2009,195)$. At base, Sidorkin rejects Dewey and his Utopians view that the intrinsic interest of the child should be what connects the child to the curriculum and ultimately to his or her work as unrealistically 
discounting the power of economic interest. In a sense, Sidorkin is right that Dewey seeks to minimize the role of economic interest in the classroom, but he fails to see why precisely Dewey does this, assuming it is simply naïveté. ${ }^{6}$

\section{The ECONOMY AND THE CURRICUlum}

Sidorkin's critique rests upon the idea that the curriculum is a sort of commodity to be acquired by the student, and teaching a kind of economic transaction. As he construes it, education is a kind of trade in which students agree to learn "boring stuff" not intrinsically interesting or particularly good for them in exchange for something they find valuable. ${ }^{7}$ He is skeptical of Dewey's belief that there is "a way to hitch the school curriculum to the authentic interests of the child" (193), because he thinks the child's interests only go so far; an interest in gardening does typically not imply one in soil chemistry. ${ }^{8}$ The solution to instruction, in his view, consists in providing the right economic incentives for doing the work of learning. "To make children work in schools," he suggests, "we can force them or we can pay them; there isn't really a third way" (193). This is why Sidorkin argues that we need "to pay students and their families for demonstrating learning that we deem important (198). This startling conclusion might make sense if one took the curriculum to be a commodity (having value only as a means to economic gain) and instruction an economic transaction, but Dewey assumes neither and consequently insists on a third way. ${ }^{9}$

To understand why Dewey thinks children not only can, but must, develop intrinsic interests intense enough to carry them deep into the curriculum, it is necessary to consider his own view of the curriculum. In The Child and the Curriculum (1902), Dewey addresses the problem of instruction; namely, how do we bring the content of the curriculum - the organized, formulated, crystallized body of all that we have learned about living in the world-into the living world of the child in the classroom? The curriculum, he argues, can't be separated from the experiences that created it without making it inert and meaningless to the child in the classroom. It will appear to be "boring stuff," and uninteresting to the degree that it retains its abstract shape. When curricular subject matter lacks "any organic connection with what the child has already seen, felt, and loved," it will seem "purely formal and symbolic" to the child (1902, 31). For Dewey, the child and the curriculum represent limits of a single process, instruction being the means by which the child is brought deeper into the knowledge the curriculum represents. The instructor's task is to provide concrete activities that connect the curriculum to the living child. He calls this "psychologizing" the curriculum, and contends that "if the subject matter ... grows out of [the child's] own past doings, thinkings, and sufferings, and grows into application in further achievements and receptivities, then no device or trick of method has to be resorted to in order to enlist "interest." The psychologized is of interest-that is, it is placed in the whole of conscious life so that it shares the worth of that life" $(1902,35)$. Accordingly, such activities are not simply pedagogical 


\section{Ian T. E. Deweese-Boyd}

sugar-coating - they are the living curriculum. This is why he rejects, as artificial, means that make the subject matter interesting for reasons having no direct connection to that subject matter, like the economic incentives Sidorkin suggests. To introduce such means would inhibit the connection necessary for the curriculum to come alive in the child.

In Dewey's view, the chief task of education is to connect the relevant parts of the curriculum to the life of the child by engaging her present interests in concrete tasks. ${ }^{10}$ Accordingly, the point of bringing something like gardening into the school is to bring the abstract facts of the curriculum into the concrete experience of the child. As Dewey explains:

Gardening ... need not be taught either for the sake of preparing future gardeners, or as an agreeable way of passing time. It affords an avenue of approach to knowledge of the place farming and horticulture have had in the history of the race and which they occupy in the present social organization. Carried on in an environment educationally controlled, they are means for making a study of the facts of growth, the chemistry of soil, the role of light, air, and moisture, injurious and helpful animal life, etc. There is nothing in the elementary study of botany which cannot be introduced in a vital way in connection with caring for the growth of seeds. Instead of the subject matter belonging to a particular study called botany, it will then belong to life, and will find, moreover, its natural correlations with the facts of soil, animal life, and human relations. (1916, 200, emphasis mine)

For Dewey, the mind doesn't stand aloof from activity; rather, it is unavoidably immersed in the processes of the world. The curriculum is an idea-it is an abstraction of actual experience, like a map; the map represents actual wanderings, real expeditions (Dewey, 1902). ${ }^{11}$ For Dewey, these abstractions are literally meaningless if they are not embedded in their relation to human activity. Occupations like gardening, then, engage students in processes that embody the subject matter of the curriculum and arouse their interests, making them agents in the process, not mere spectators. The difference between the spectator and agent is in the sort of interest taken in an activity; the spectator, having no stake and no means to shape the outcome, is indifferent; the agent, having a deep concern over the foreseen ends, is eager to determine the best way to reach them. An occupation like gardening gives students the opportunity to be agents. Depending on age, this interest will take different forms. A five-year-old may simply want to see the wheat sprout and grow green, while an older child might want to see whether she can get her plants to produce more tomatoes this year than last. As Dewey suggests, over the course of years students "will perceive problems of interest which may be pursued for the sake of discovery, independent of the original direct interest in gardening" (200). To the question, "How, upon this basis, shall the child get the needed information; how shall he undergo the required discipline?" (1902, 59), Dewey, like the Uto- 
pians, responds that this is really the wrong sort of question. It assumes that the curriculum is simply information to be acquired and that discipline is something valuable in its own right. Instead, the curriculum is of use in the context of activities undertaken, and discipline is necessary only in the context of reaching desired ends. Like a map, it is useful only to those who want to go somewhere. ${ }^{12}$

Only children genuinely interested in something will develop the ability to inquire, to identify and solve problems, or, to return to the map metaphor, to chart new territories, by adding to the store of knowledge represented by the curriculum. Accordingly, the linchpin to Dewey's educational vision is the development of the attitudes that make the child, and later the adult, keen to understand and energetic for the search. Intrinsic interest, then, isn't simply a means for acquiring curricular content-it's an end in its own right.

Sidorkin's critique of Dewey's use of occupations relies upon the mistaken view that they serve simply as means for delivering the content of the curriculum and that interest is only a pedagogical tool. Dewey's concern to develop the capacity for intrinsic interest, however, goes much deeper than this. Ultimately, the ability to find deep interest in occupations-interest that embraces not only their curricular content, but also their social value-prepares the child to find meaning, pleasure, and social significance in her work as an adult, as Dewey's account of vocation makes clear. ${ }^{13}$

\section{Vocation, DemOCRACY, AND UTOPIA}

For Dewey, a vocation is meaningful activity that matches one's aptitude and interest to needs of the community of which one is a member. Thus, he writes in Democracy and Education, "To find out what one is fitted to do and to secure an opportunity to do it is the key to happiness. Nothing is more tragic than failure to discover one's true happiness in life, or to find that one has drifted or been forced by circumstance into an uncongenial calling" $(1916,308)$. Ideally, then, schools assist students in the discovery of "what they are good for," helping them to identify and develop their capacities in a way that serves social needs and provides personal meaning (307-09). As we have seen, the schools of Utopia focus almost exclusively on this task. For them, the curriculum's utility is found first in the discovery of the child's specific potential, and second, in identifying the path best suited for developing it. The faith of both Dewey and his Utopians is that students afforded the opportunity to develop their potential in ways directly interesting to them will not only be personally happy, but also socially useful. Dewey and his Utopians see the acquisitive society as a threat to this task because it introduces pressures that alienate people from their true callings.

When identifying the greatest evil of the present state of society, Dewey (1916) points to "the fact that so many persons have callings which make no appeal to them, which are pursued simply for the money reward that accrues" (317). Such 


\section{IAn T. E. DeweEse-Boyd}

people lack economic freedom in the sense that "their pursuits are fixed by accident and necessity of circumstances," and, as a consequence, these pursuits "are not the normal expression of their own powers interacting with the needs and resources of the environment" (136). The implication is that work might spring from the normal expression of a person's capacities in the context of purposes that engage her interests. Such work, while no doubt having economic value, would neither be determined by nor pursued primarily for the sake of its economic value; such work would be a "vocation" in Dewey's sense. When economic factors force one into work that does not connect to personal interest, neither the heart nor the mind is deeply engaged. ${ }^{14}$ In view of these things, it is clear why fostering a sense of intrinsic interest is essential for schoolwork, and why Dewey explicitly rejects appeals to economic rewards of the sort Sidorkin (2009) recommends.

Schools provide a place in which occupations may, freed from the distorting effects of the economy, be pursued for their own sakes. Pursued in this way, they have enormous pedagogical value, since they bridge the great gap between the life of the child and the content of the curriculum. But their value extends beyond such academic concerns, since what is cultivated in the process of such an education is the capacity to find and pursue one's interests with devotion and discipline.

In Dewey's view, helping students find their vocation involves not only the identification and development of their abilities, but also the fostering of their appreciation of the ways their abilities connect to the needs of society. Part of what students gain from pursuing occupations in school-where they have been "freed from ... the pressures of wage-earning" $(1916,200)$ - is the ability to grasp their social value or, as Dewey puts it, their connection to "fundamental common concerns" $(1916,199) .{ }^{15}$ Engaging in occupations, then, raises awareness of social interdependence. "An occupation," in its most genuine sense, "balances the distinctive capacity of an individual with his social service" $(1916,308)$. In Dewey's view, to the degree that people are able to engage in occupations of this sort, their work "makes the lives of others better worth living, and ... makes the ties which bind persons together more perceptible [thereby breaking] down the barriers of distance between them" $(1916,316)$. Insofar as democracy itself is a mode of communicated experience measured by the number and quality of connections and shared interests, a society in which people have found their vocations would be thoroughly democratic in Dewey's sense. In such a society, people would find intrinsic interest in their work uncoerced by extrinsic economic factors. In short, such a society would be very similar to the Utopia that stands on the other side of the acquisitive economy.

Though Dewey sees that such a society may seem a distant dream, nothing ultimately stands in the way of its realization if the appropriate educational reforms are adopted, if basic dispositions of the next generation are altered. Such an alteration in attitude, he thinks, can only be accomplished by transforming the society of the school itself: "We may produce in schools a projection in type of the 
society we should like to realize, and by forming minds into accord with it gradually modify the larger and more recalcitrant features of adult society" $(1916,317)$. Accordingly, the path to Utopia is thoroughly educational in nature, and, paradoxically, utopian education turns out to be the means by which this transformation is accomplished, not simply its result.

Both the vision for such social transformation and the faith in the educational means he advocates stem from Dewey's faith in the ideal of radical democracy, an ideal that Richard Bernstein (2010) insists functions as "an end-in-view that can guide our actions here and now. It is an ideal that serves as a critical standard for evaluating the deficiencies of 'really existing' democracies and serves also as a guide for concrete action" (295). It functions, then, like Oscar Wilde's map, like the curriculum itself, locating us and equipping us for the never-ending "utopian task of shaping the future" (McKenna 2001, 101). ${ }^{16}$

\section{Notes}

1. John Dewey, "Dewey Outlines Utopian Schools," The Later Works, 1925-1953 (vol. 9, 1933-1934), edited by J.A. Boydston (Carbondale: Southern Illinois University Press, 1989).

2. See, for example, Juliet Schor, Born to Buy: The Commercialized Child and the New Consumer Culture (New York: Scribner, 2004).

3. John Dewey, "Dewey Outlines Utopian Schools," The Later Works, 1925-1953, vol. 9 , 1933-1934, edited by J. A. Boydston (Carbondale: Southern Illinois University Press, 1989). Dewey's explanation of the way that teachers are selected and trained is an apt example of this apprenticeship model. Teenagers who are especially fond of children are given the opportunity to work with them under the observation of adult teachers to determine whether they have the "taste, interest and the kind of skill which is needed for effective dealing with the young" $(1933 / 1989,137)$. Those who do have such skill and interest are given the opportunity to study child development, and other educationally relevant subjects. All along they are practicing what they are learning, deepening their interest and sharpening its application. Dewey describes the adult leaders-teachers-this way: "The adult leaders, through their previous experience and by the manner of their selection, combine special knowledge of the children with special gifts in certain directions" $(1933 / 1989,137)$. Their education is a kind of natural selection; the key is to determine where their interest and aptitude meet. This example also suggests the close connection between education and vocation, which I will take up in the last section of this paper.

4. See Alexander M. Sidorkin, "John Dewey: A Case of Utopianism," in Philosophy of Education 2009, edited by Deborah Kerdeman, 191-99 (Urbana, IL: Philosophy of Education Society, 2009).

5. Kurt Stemhagen, "Dewey as Utopian: Labor Versus Leisure, Mass Media as Democratic Education, and the Future of Public Schooling," in Philosophy of Education 2009, edited by Deborah Kerdeman, 200-03 (Urbana, IL: Philosophy of Education Society, 2009). "Utopia", of course, has a beautiful ambiguity about it, being either a "good place" or "no place" at all. Stemhagen (2009) uses Lewis Mumford's distinction between "utopias of escape" and "utopias of reconstruction" to clarify and critique Sidorkin's (2009) charge of "utopianism." In Stemhagen's view, Dewey is a utopian of reconstruction; that is, a utopian who imagines a better 


\section{IAn T. E. DeweESE-Boyd}

place as a means for navigating to it. Sidorkin takes Dewey to be a utopian of escape, dreaming of a place that never can be. Like Stemhagen, I argue that Dewey is "no idle dreamer-his educational prescriptions were actions toward broader social improvement" $(2009,200)$.

6. Kurt Stemhagen and Nakia S. Pope, "Democracy, Capitalism, and Education: Reconsidering Dewey's Failure to Address Economic Life," in Philosophy of Education 2012, edited by Claudia W. Ruitenberg, 306-14 (Urbana, IL: Philosophy of Education Society, 2012). Stemhagen and Pope offer a detailed response to Samuel Bowles and Herbert Gintis's similar accusation that Dewey naïvely underestimated the power of capitalism when he made his recommendations for education reform [see Bowles and Gintis, Schooling in Capitalist America (New York: Basic Books, 1976)]. Drawing on works spanning Dewey's entire writing career, Stemhagen and Pope argue that, contrary to Bowles and Gintis, Dewey was "not naïve as to the effects of our economic system on schooling. He was keenly aware of the negative effects of capitalism and his plan was designed explicitly to address these effects" $(2012,308)$.

7. Cf. Sidorkin, "John Dewey: A Case of Utopianism," 2009, 193, 198. Sidorkin contends that Dewey's view that there is an authentic way to connect the curriculum to the intrinsic interests of the child flawed. In his view, to get the child to learn something that she isn't directly interested in learning, Dewey unconsciously relies upon teacher authority founded on what Sidorkin calls "relational capital." Roughly, a teacher builds her stock of relational capital, her store of student good will, "by giving students what they want: interesting activities, meaningful conversations, and honest relationship" (Sidorkin 2009, 195). This capital is then used to get students to do what they are not really interested in doing. This exchange, this "interest transfer," is the heart of progressive education, according to Sidorkin. While this account of Dewey and progressive education is itself questionable, Sidorkin's point is that even this relational capital will prove insufficient to motivate learning. This is why he thinks economic interests and incentives must play a role in motivating learning.

8. Even when intrinsic interest is combined with the good will earned by a teacher providing students with fun activities like gardening, Sidorkin thinks, it will be too meager to motivate students to master the curriculum. His worry about Dewey, then, is that he ignores powerful competing economic interests. Sidorkin (2009) contends that "children will return the favor or comply with adult demands within reason, but not beyond... . The question of reasonable exchange is what economics is all about. Economics is a study of limits, of figuring out who owes how much to whom" (195-96).

9. Stemhagen (2009), in a response to Sidorkin, argues that this sharp distinction between labor and inherently meaningful activity represents a view that interest and effort are primarily a function of external factors, attractive wrappings to draw interest, overt pressure to motivate effort. As Stemhagen carefully explains, Dewey's view is that interest is internal to the agent and is precisely what drives the effort to lay hold of the object of interest and make it one's own. According to Stemhagen, then, "for Dewey if schooling is working well, children do not need to be forced or paid" $(2009,201)$ because interest properly focused and given play will be enough to ensure that learning is meaningful activity. I argue along similar lines below, focusing on the way Dewey's notion of work and vocation aims at cultivating just this sort of interest. For more on Dewey's view of interest, see Mark E. Jonas, "Dewey's Conception of Interest and Its Significance for Teaching Education," Educational Philosophy and Theory 43, no. 2 (2011): 112-29.

10. John Dewey, Democracy and Education (New York: Macmillan, 1916). As Dewey says, "The problem of instruction is ... that of finding material which will engage a person in specific activities having an aim or purpose of moment or interest to him and dealing with things ... as the condition for the attainment of ends" $(1916,132)$. 
11. John Dewey, The Child and the Curriculum (Chicago: University of Chicago Press, 1902). Dewey likens the curriculum to a map that organizes the many actual explorations people have made into a coherent whole. In the hands of a guide, its use is locating the particular student, seeing where she is and what paths through the terrain will be most beneficial to her.

12. Even if interest is central to authentic learning, Sidorkin still finds Dewey's use of occupations insufficient to motivate learning because students' interests differ so widely. To think most children would have an interest in gardening is "naïve at best, ignorant at worst" $(2009,195)$. Dewey himself acknowledges as much, though he is perhaps more optimistic about children's capacity for wonder and desire for understanding. Accordingly, Dewey (1916) writes: "In the concrete, the value of recognizing the dynamic place of interest in an educative development is that it leads to considering individual children in their specific capabilities, needs, and preferences. One who recognizes the importance of interest will not assume that all minds work in the same way. . . . Attitudes and methods of approach and response vary with the specific appeal the same material makes, this appeal itself varying with difference of natural aptitude, of past experience, of plan of life, and so on" (130). The Utopian schools address this reality by providing a wide variety of contexts in which the facts of the curriculum can be encountered. If a child has little interest in gardening but finds anything to do with vehicles fascinating, then it will be in that context that she comes to see the significance of mathematics, physics, chemistry, history, and so forth. Sidorkin's concerns arise from schools as we know them; the Utopian schools allow for children to mix with younger and older peers and to choose from a wide variety of occupations. Sidorkin is clearly right that making everyone in the class garden may not arouse the sort of interest Dewey is talking about, but that is the fault of the structure of the school, not the notion of interest. This is Dewey's point in saying that there are no schools in Utopia.

13. Jonas, "Dewey's Conception of Interest," 2011. Jonas's excellent analysis of "interest" in Dewey helps to highlight this point. For Dewey, interest is a matter of identity and self-expression. Jonas writes, "Dewey believes that students become interested in a particular object... when they regard that object as so important that if they cannot apprehend it-absorb it, so to speak, through physical or psychical interaction - they will not be able to be the individuals they desire to be" (115). Interest, in this sense, clearly carries with it both motivation and meaning.

14. Dewey argues that this interest isn't merely individual, but also social. An interest in gardening, for instance, arises from and answers to a larger social need, namely, the feeding of the hungry. It's this value that strikes deep interest, and, paradoxically, it's this value that is often obscured by the pressures of purely economic interest. As Dewey (1916) points out, "If the mass of mankind has usually found in its industrial occupations nothing but evils which had to be endured for the sake of maintaining existence, the fault is not in the occupations, but in the conditions under which they are carried on" (200). The economy itself seems to play a significant role in creating these conditions, reducing work to a mere means for gaining money and maintaining existence.

15. Stemhagen and Pope (2012) make a similar point regarding the value of occupationcentered or vocational schooling in Dewey's philosophy of education (cf. 307-10).

16. I want to thank the two anonymous reviewers for exceptionally helpful feedback on this essay, which helped me to connect it to the larger discussion of utopian thinking and Dewey's work. 


\section{BIBLIOGRAPHY}

Bernstein, R. "Dewey's Vision of Radical Democracy." In The Cambridge Companion to Dewey, edited by Molly Cochran, New York: Cambridge University Press, 2010. Dewey, John. The Child and the Curriculum. Chicago: University of Chicago Press, 1902. - - Democracy and Education. New York: Macmillan, 1916. . "Dewey Outlines Utopian Schools." The Later Works, 1925-1953 (vol. 9, 19331934). Edited by J.A. Boydston. Carbondale: Southern Illinois University Press, 1989. - - . The School and Society. Chicago, IL: University of Chicago Press, 1900.

Jonas, Mark E. "Dewey's Conception of Interest and its Significance for Teacher Education." Educational Philosophy and Theory 43, no. 2 (2011): 112-29.

McKenna, E. The Task of Utopia: A Pragmatist and Feminist Perspective. Lanham, MD: Rowman and Littlefield, 2001.

Schor, Juliet. Born to Buy: The Commercialized Child and the New Consumer Culture. New York: Scribner, 2004.

Sidorkin, Alexander M. "John Dewey: A Case of Educational Utopianism." In Philosophy of Education 2009, edited by Deborah Kerdeman, 191-99. Urbana, IL: Philosophy of Education Society, 2009.

Stemhagen, Kurt. "Dewey as Utopian: Labor Versus Leisure, Mass Media as Democratic Education, and the Future of Public Schooling." In Philosophy of Education 2009, edited by Deborah Kerdeman, 200-03. Urbana, IL: Philosophy of Education Society, 2009.

Stemhagen, Kurt, and Nakia S. Pope. "Democracy, Capitalism, and Education: Reconsidering Dewey's Failure to Address Economic Life." In Philosophy of Education 2012, edited by Claudia W. Ruitenberg, 306-14. Urbana, IL: Philosophy of Education Society, 2012.

Wilde, Oscar. The Soul of Man Under Socialism and Selected Critical Prose. Edited by Linda Dowling. New York: Penguin, 2001.

Ian T. E. Deweese-Boyd is an associate professor in the Philosophy Department at Gordon College in Wenham, MA. Email: ian.deweese.boyd@gordon.edu 